\title{
Comparison of Iloprost and Papaverine in Topical Vasodilation of Internal Mammary Artery in Coronary Artery Bypass Grafting: A Prospective Randomized Trial
}

\author{
Emine Şeyma Denli Yalvaç ${ }^{1}, \odot$ Ozan Onur Balkanay², ${ }^{2}$ Deniz Göksedef ${ }^{2}$, $\odot$ Suat Hilal Aki ${ }^{3}$, \\ Suat Nail Ömeroğlư ${ }^{2}, \odot$ Gökhan İpek ${ }^{2}$ \\ ${ }^{1}$ Department of Cardiovascular Surgery, Medeniyet University, Goztepe Training and Research Hospital, Istanbul, Turkey \\ ${ }^{2}$ Department of Cardiovascular Surgery, Istanbul University Cerrahpasa Faculty of Medicine, Istanbul, Turkey \\ ${ }^{3}$ Department of Pathology, Istanbul University Cerrahpasa Faculty of Medicine, Istanbul, Turkey
}

\begin{abstract}
Introduction: Internal mammary artery (IMA) graft is a commonly used coronary artery bypass conduit due to its high longterm patency rates. IMA may have a perioperative arterial spasm problem. Papaverine, an opium alkaloid, is commonly used in vasospasm, especially for IMA. Iloprost, a synthetic prostacyclin analogue, could be an alternative to papaverine. In this study, we compared the effects of topical iloprost and papaverine concerning the prevention of IMA vasospasm.

Methods: Between May-August 2009, 40 consecutive patients who underwent coronary artery bypass grafting using IMA graft were included in this prospective study. Patients were divided into two groups to be treated with topical vasodilators as iloprost and papaverine groups. The free blood flow of IMA was measured before and after the topical vasodilators were applied. These results were evaluated together with concurrently measured mean arterial pressures. Histopathologic examination was performed with the distal part of IMA and scored according to the desquamation rate.

Results: Preoperative and haemodynamic parameters between the two groups were similar. With both vasodilator agents, the amount of IMA blood flow was increased in a similar ratio as well. Analysis of this increase was assessed by dividing the blood flow by the mean arterial blood pressure value. Iloprost group had similar vasodilation response when compared with the response of the papaverine group. There was more desquamation in the papaverine group at a significant level. There was no significant difference between the two groups in terms of postoperative mortality and complications.

Discussion and Conclusion: We concluded that iloprost could be an alternative for papaverine with similar vasodilation response and lower level of endothelial damage.

Keywords: Coronary artery bypass grafting; endothelium; graft spasm; internal mammary artery; iloprost; vascular relaxation.
\end{abstract}

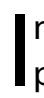
n coronary artery bypass grafting (CABG) surgery, the preferred graft is the internal mammary artery with high patency rates. The 10-year patency rate is approximately $85-95 \%$ in the internal mammary artery (IMA) and 38-45\% in great saphenous vein (GSV) grafts $^{[1]}$. However, the risk of perioperative spasm of arterial grafts is an important complication for $\mathrm{CABG}^{[2]}$. Many methods have been developed to prevent this complication, which can be usually unpredictable and cause perioperative morbidity and mortality, resulting in significant reductions in revascularized coronary artery flow when it occurs ${ }^{[3,4]}$. Over-manipulation of the IMA and dissections by high-voltage cautery

Correspondence (iletişim): Ozan Onur Balkanay, M.D. Istanbul Universitesi Cerrahpasa Tip Fakultesi Kalp ve Damar Cerrahisi Anabilim Dali, Cerrahpaşa, Fatih, İstanbul, Turkey

Phone (Telefon): +90 (212) 41430 00-23129 E-mail (E-posta): balkanay@doctor.com

Submitted Date (Başvuru Tarihi): 08.01.2020 Accepted Date (Kabul Tarihi): 10.01.2020

Copyright 2020 Haydarpaşa Numune Medical Journal

OPEN ACCESS This is an open access article under the CC BY-NC license (http://creativecommons.org/licenses/by-nc/4.0/).

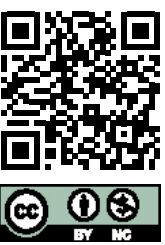


during the exploration and preparation phase of the graft cause the secretion of thromboxane from the intimal layer. Thromboxane is the leading cause of IMA spasm ${ }^{[5]}$. Therefore, after IMA is prepared, it is tried to increase the blood flow of IMA by topical vasodilation ${ }^{[6,7]}$. It has been reported that intimal injuries and early and late IMA patency rates may be adversely affected by procedures other than topical vasodilators ${ }^{[8]}$. The first agent used as a topical vasodilator was papaverine ${ }^{[6,8]}$. The success of topical papaverine in reversing the spasm in the IMA has led to other vasodilators as the papaverine alternative. lloprost is an analogous agent to prostacyclin $\left(\mathrm{PGI}_{2}\right)$, a short-lived substance made by vascular endothelial cells. $\mathrm{PGI}_{2}$ has vasodilator and cell protectiveeffects, such as inhibition of platelet aggregation, activation and also 5-hydroxytryptamine (5-HT) and thromboxane release from activated platelets. Due to these features, lloprost has found its use in cardiac surgery by reducing the pulmonary vascular resistance and protecting the right ventricle, especially in patients with mitral stenosis. IMA's response to vasoconstrictors, such as endothelin-1, thromboxane $A_{2^{\prime}}$ norepinephrine, and 5-HT, may change. Although the most potent vasoconstrictor is endothelin-1, the most effective is thromboxane $A_{2}$. This suggests that endothelin- 1 and thromboxane $A_{2}$ play an important role in arterial spasm ${ }^{[9]}$. To our knowledge, there is no study yet to evaluate the efficacy of iloprost, which inhibits the release of thromboxane that causes IMA spasm, on topical application of IMA, compared with papaverine and whether this effect is significant. In our study, we aimed to compare the vasodilation effects and level of endothelial damages between topical iloprost and papaverine on IMA used in CABG.

\section{Materials and Methods}

Forty consecutive patients with elective CABG with left IMA grafting were included in this study between May-August 2009 after approval of the local ethics committee (Approval number: 13735). The patients were randomized and divided into two groups after the informed consents were taken. Twenty patients in group 1 were used papaverine as a topical vasodilator and the other 20 patients in group 2 were used iloprost as a topical vasodilator. Preoperative risk factors were compared concerning hypertension, diabetes mellitus, peripheral artery disease, hyperlipidemia, smoking history, cerebrovascular event, and left ventricular dysfunction (Table 1). The clinical status and the angina pec-

Table 1. Preoperative patient data

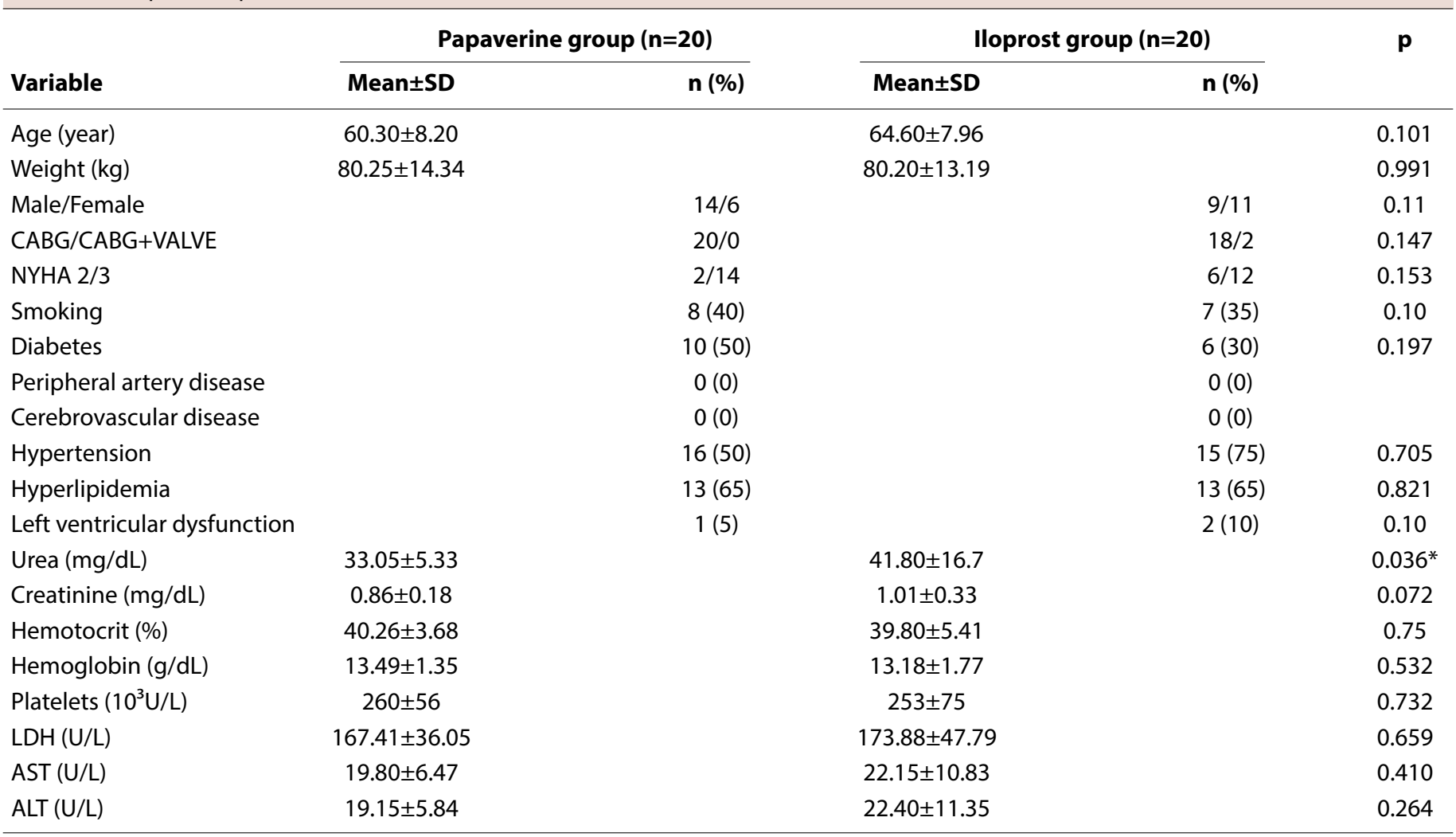

ALT: Alanine aminotransferase; AST: Aspartate aminotransferase; CABG: Coronary artery bypass grafting; CABG+VALVE: Coronary artery bypass grafting + valve repair/replacement; LDH: Lactate dehydrogenase; NYHA: New York Heart Association class 2/class 3; SD: Standard deviation; *: Statistically significant ( $<<0.05$ ). 


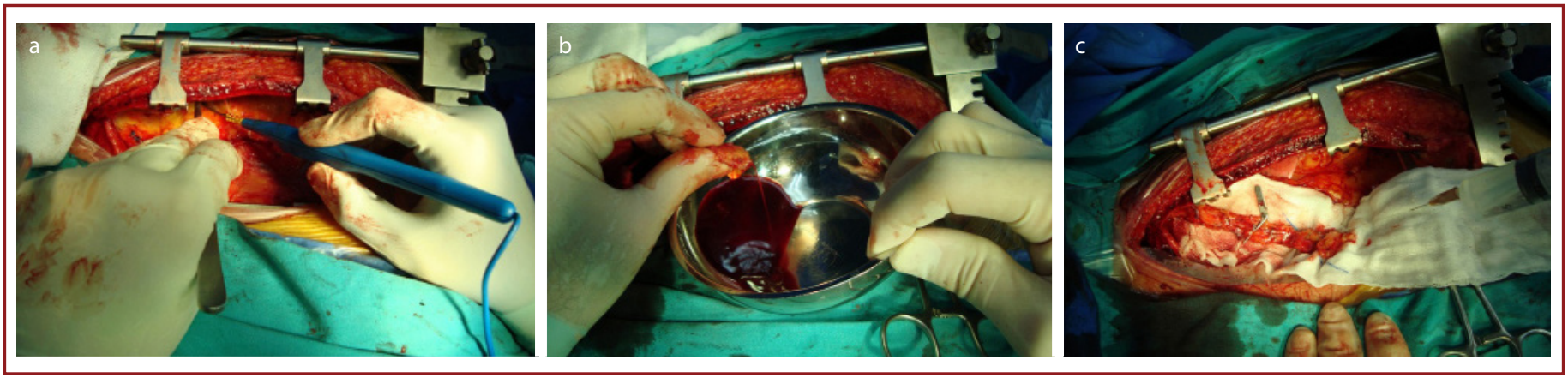

Figure 1. Internal mammary artery graft. (a) Preparation of the graft using the electro-cautery; (b) Blood flow measurement of the graft; (c) Application of the vasodilator agent.

toris characters of patients were assessed according to the NYHA (New York Heart Association) and CANADA (Canadian Cardiovascular Association Angina Pectoris) classifications. In both classifications, class 2 and class 3 categories, nearly $90 \%$ of the patients were compared statistically. Preoperative laboratory results (hemogram, hematocrit, blood urea nitrogen, serum creatinine, platelet, lactate dehydrogenase, bilirubin and transaminases) of the patients were compared between the two groups (Table 1).

\section{Surgical Technique and Procedure}

All patients were operated using standard median sternotomy. Left IMA was prepared with a pedicle using the electrocautery and hemoclip from the level of the first intercostal side to distal bifurcation (Fig. 1a). Immediately after the left IMA was prepared, a 60-second IMA blood flow (Flow-1) was measured by providing free blood flow to a container (Fig. 1b). After the initial measurement, the IMA tip was closed with a soft-tipped bulldog clamp and the IMA pedicle was placed. Thus, there was no torsion on the surgical gause. In the patient to be injected with papaverine, Papaverin $2 \mathrm{~mL}$ (Papaverin $\mathrm{HCl} 0.05 \mathrm{~g} / 2 \mathrm{~mL}$, Biosel ${ }^{\oplus}$, Istanbul) was diluted using $8 \mathrm{~mL}$ of isotonic sodium chloride, and iloprost $1000 \mathrm{ng}$ in the group to be injected iloprost (llomedin $20 \mu \mathrm{g} / 1 \mathrm{~mL}$, Bayer Schering ${ }^{\circledR}$, Germany) was sprayed onto the IMA pedi- cle from a syringe fitted with a $26 \mathrm{G}$ needle, diluted with 10 $\mathrm{mL}$ isotonic sodium chloride (Fig. 1c).

The pedicle was then wrapped with the same gause and kept in this gause until the other measurements were made. For the initiation of the cardiopulmonary bypass, ascending aortic arterial cannulation and right atrial two-stage venous cannulation. Bicaval cannulation was performed from the right atrium in case of additional valve replacement for coronary artery bypass operation. The free blood flow of IMA was measured (Flow-2) for 60 seconds just before the initiation of the cardiopulmonary bypass. An antegrade cardioplegia cannula was placed at the aortic root and a retrograde cardioplegia cannula to the coronary sinus. All cases were arrested by isothermic blood cardioplegia. During the operation, myocardial protection was provided by retrograde isothermic blood cardioplegia. A membrane oxygenator was used in all cases. During the operation, mild hypothermia was applied at $28-32^{\circ} \mathrm{C}$. During the cardiopulmonary bypass, a 60 -second IMA blood flow (Flow-3) was measured before the IMA anastomosis. All the measurements were recorded simultaneously with mean blood pressure values. The differences between the measured blood flow rates of the patients and the simultaneous mean arterial pressure ratios between Flow-1, Flow-2 and Flow-3 were evaluated for each patient and the two groups were compared (Table

Table 2. Internal mammary artery graft blood flow comparisons

\begin{tabular}{|c|c|c|c|}
\hline Variable & $\begin{array}{c}\text { Papaverine group }(n=20) \\
\text { Mean } \pm S D\end{array}$ & $\begin{array}{l}\text { Iloprost group }(n=20) \\
\text { Mean } \pm S D\end{array}$ & $\mathbf{p}$ \\
\hline Flow-1/MAP (mL/min/mmHg) & $0.32 \pm 0.17$ & $0.40 \pm 0.23$ & 0.249 \\
\hline Flow-3/MAP $(\mathrm{mL} / \mathrm{min} / \mathrm{mmHg})$ & $0.51 \pm 0.15$ & $0.57 \pm 0.25$ & 0.429 \\
\hline [(Flow-2/MAP) - (Flow-1/MAP )]/(Flow-1/MAP) (\%) & $156.94 \pm 188.15$ & $100.05 \pm 78.35$ & 0.418 \\
\hline
\end{tabular}

Flow-1: Internal mammary arterial graft blood flow immediately after the preparation of the graft; Flow-2: Internal mammary arterial graft blood flow just before the initiation of cardiopulmonary bypass; Flow-3: Internal mammary arterial graft blood flow just before the anastomosis; MAP: Mean arterial blood pressure. 
2). The aim was to demonstrate vasodilation of the IMA graft with reduced vasospasm and topical vasodilator treatment and to compare this effect with both groups. Thus, Flow-1 and Flow- 2 were compared first. The Flow- $1 /$ mean arterial tension ratio was subtracted from the Flow-2/mean arterial tension ratio and divided by the Flow-1/mean arterial tension ratio, and the results were compared between groups (Table 2). Secondly, Flow-1 and Flow-3 were compared. The Flow- $1 /$ mean arterial tension ratio was subtracted from the Flow-3/mean arterial tension ratio and divided by the Flow-1/mean arterial tension ratio, and the results were compared (Table 2). After the Flow-3 was measured, approximately $3 \mathrm{~mm}$ of the distal portion of the pedicle was cut and fixed in a buffered $10 \%$ formalin solution. After transparency with toluene, the samples were blocked after paraffin inclusion and evaluated with light microscopy at the level of hematoxylin-eosin staining to show general vascular histology by passing through increasing alcohol series (70\%, 90\%, 96\%, 100\%). Pathological damage was scored by considering endothelial cell loss, basal lamina, intimal and medial edema as: Score 0 for no damage; score 1 for slight damage and mild desquamation of endothelium; score 2 for moderate damage and moderate-severe desquamation of the endothelium; and score 3 for severe damage and severe desquamation of the endothelium. All IMAs used in this study were anastomosed to the left anterior descending (LAD) artery. The patients were followed up during the operative period and the discharge period.

\section{Statistical Methods}

All categorical variables were expressed as number and percentage, while continuous variables were expressed as mean \pm standard deviation. All of the demographic, preoperative, operative and postoperative values of each group were compared. Normally distributed data of parametric variables among groups were compared using Student's t-test. Otherwise, Mann-Whitney U-test was used. Nonparametric variables were compared using the Chi-square test and Fisher's exact test. A p-value of less than 0.05 was accepted as significant.

\section{Results}

There was no statistically significant difference between the two groups concerning patient gender (male/female ratio), age and weight (Table 1). There were no significant differences between the two groups concerning risk factors and NYHA, CANADA classifications. Two patients in the iloprost group had valve (aorta) and coronary artery disease together. The preoperative blood urea nitrogen value was lower in the papaverine group. There was no significant difference between the groups about other preoperative laboratory results (Table 1 ).

In both groups, there was no clinical finding to suggest perioperative IMA spasm. There was no statistically significant difference between the two groups concerning operative values (cross-clamp time, total perfusion time, the total amount of bleeding and use of blood products) that could affect the IMA blood flow during the measurement phase (Table 3). Perioperative MI developed in one patient. Topical vasodilators significantly increased IMA blood flow despite a significant decrease in mean blood pressure ( $p=0.044$ for iloprost group, $p=0.003$ for papaverine group). In the comparison of the two groups, it was determined that there was no statistical difference between the rates of graft blood flows recorded in three different time points (Flow 1-3). Both groups significantly increased the IMA current after topical application in itself, but this increase was not significantly different between the groups (Table 2).

There was no significant difference between the two groups concerning mortality and morbidity and postoperative variables as intensive care unit follow-up time, discharge time, use of the inotropic agent, arrhythmia (atrial fibrillation, ventricular fibrillation), low cardiac output syndrome and intra-aortic balloon pump requirement (Table 3).

During the pathologic evaluation, mild desquamation was observed at $1^{\text {st }}$ grade in nine samples of the papaverine group and two samples in the iloprost group. This difference was significant ( $p=0.013$ ) (Fig. 2). The desquamation was not observed in any of the samples at medium $\left(2^{\text {nd }}\right)$ or advanced ( $3^{\text {rd }}$ ) grade. A total of 11 samples with a slight degree of desquamation, seven of fibrotic, three of fibrotic and calcific plaques were observed. All patients with desquamation were hyperlipidemic and did not receive antilipidemic treatment pre-operatively.

\section{Discussion}

\section{Papaverine}

Papaverine is an alkaline isoquinoline derivative. It is believed that the effects on smooth muscle cells are related to the inhibition of phosphodiesterase enzyme in cells. Some intra-cerebral vascular pathologies can be used parenterally or topically. Papaverine is the first and commonly used topical used agent for IMA grafts ${ }^{[6,8]}$. Due to the acidic structure, papaverine may lead to endothelial damage when intensively prepared. The $\mathrm{pH}$ of the isotonic solution 
Table 3. Peroperative and postoperative patient data

\begin{tabular}{|c|c|c|c|c|c|}
\hline \multirow[b]{2}{*}{ Variable } & \multicolumn{2}{|c|}{ Papaverine group $(n=20)$} & \multicolumn{2}{|c|}{ Iloprost group (n=20) } & \multirow[t]{2}{*}{$\mathbf{p}$} \\
\hline & Mean \pm SD & n (\%) & Mean \pm SD & n (\%) & \\
\hline ACCT (minutes) & $62.25 \pm 27.49$ & & $66.05 \pm 29.02$ & & 0.673 \\
\hline TPT (minutes) & $91.55 \pm 35.54$ & & $94.15 \pm 35.41$ & & 0.818 \\
\hline ES transfusion (unit) & $0.35 \pm 0.75$ & & $0.35 \pm 0.67$ & & 1 \\
\hline FFP transfusion (FFP) (unit) & $0 \pm 0$ & & $0.1 \pm 0.30$ & & 0.163 \\
\hline Peroperative Ml & & $0(0)$ & & $1(5)$ & 0.311 \\
\hline Extubation time (hour) & $15.89 \pm 4.2$ & & $12.95 \pm 5.5$ & & 0.498 \\
\hline Inotropic use & & $6(30)$ & & $5(25)$ & 0.723 \\
\hline IABP & & $0(0)$ & & $1(5)$ & 0.311 \\
\hline Low cardiac output & & $0(0)$ & & $1(5)$ & 0.311 \\
\hline Atrial fibrillation & & $2(10)$ & & $5(25)$ & 0.212 \\
\hline Ventricular fibrillation & & $0(0)$ & & $0(0)$ & \\
\hline Use of blood products & & $10(50)$ & & $8(40)$ & 0.618 \\
\hline Bleeding $(\mathrm{mL})$ & $1043 \pm 181$ & & $975 \pm 326$ & & 0.496 \\
\hline ICU time (hour) & $60.9 \pm 33.8$ & & $56.2 \pm 18.9$ & & 0.586 \\
\hline Postoperative infection & & $0(0)$ & & $0(0)$ & \\
\hline Discharge time (day) & $9.2 \pm 1.1$ & & $9.95 \pm 3.2$ & & 0.1 \\
\hline
\end{tabular}

ACCT: Aortic cross clamp time; ES: Erythrocyte suspension; FFP: Fresh frozen plasma; IABP: Intraaortic balloon pump; ICU: Intensive care unit; MI: Peroperative myocardial infarction; TPT: Total perfusion time.

prepared with a concentration of $2.5 \mathrm{mmol} / \mathrm{L}$ was measured as $\mathrm{pH} 4.4$, while the isotonic solution prepared with a concentration of $0.03 \mathrm{mmol} / \mathrm{L}$ was measured as $\mathrm{pH} 4.8^{[10]}$.

\section{Prostacyclin}

Prostacyclin $\left(\mathrm{PGI}_{2}\right)$ is synthesized from arachidonic acid, with a half-life of 10 seconds. $\mathrm{PGl}_{2}$ activates the enzyme adenyl cyclase in vascular smooth muscle cells, resulting in increased intracellular CAMP, which leads to vasodilation. Factors that stimulate release are pulsatile pressure, bradykinin, thrombin, serotonin, and platelet-derived growth factor ${ }^{[11]}$. $\mathrm{PGl}_{2}$ also plays an important role in the regulation of microvascular blood flow and inhibition of platelet aggregation.

\section{lloprost}

After $\mathrm{PGI}_{2}$ was enumerated by Vane et al. ${ }^{[12]}$ in 1976 and iloprost was produced in 1978. Prostacyclins are biologically active mediators released from endothelial cells, smooth muscles, pericytes, fibroblasts, mast cells, leucocytes and platelets. $\mathrm{PGI}_{2}$ is a non-stable metabolite. Vasoactive functions are thought to be important in ischemia-reperfusion injury. Vascular smooth muscle increases cAMP concentration, inhibits platelet aggregation and causes vasodilation $[13,14]$. Iloprost is a prostacyclin analogue, an antagonist that also provides potent vasodilation and endothelial integrity. Pharmacokinetic properties are very close to $\mathrm{PGI}_{2}$. Structural features that distinguish iloprost from prostacyclin are
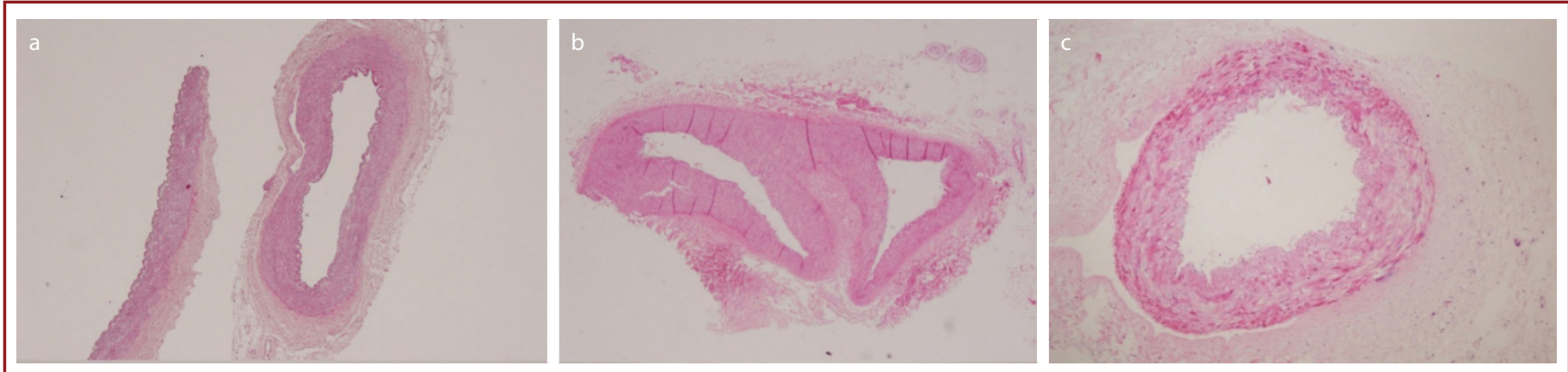

Figure 2. Pathological specimens of internal mammary artery graft. (a) Normal endothelium without desquamation in the iloprost group; (b) Mild desquamation in the iloprost group; (c) Mild desquamation in the papaverine group 
the methyl group at C16, the triple bond at positions $18 / 19$, and the enol oxygen group at the site of the methane ${ }^{[15]}$. lloprost is chemically and metabolically stable. Half-life is 20-30 minutes. It is not affected by light. Total clearance with iloprost metabolites is $20-24 \mathrm{~mL} / \mathrm{min} / \mathrm{kg}$, indicating that iloprost is a significant extrahepatic biomarker ${ }^{[16]}$.

There are considerable effects of iloprost: Vasodilatation, inhibition of leukocyte activation and adhesion (leukocyte/ vessel wall interaction ${ }^{[17-20]}$, activation of the platelet aggregation, as well as active inhibition of $5-\mathrm{HT}$ and thromboxane release from platelets ${ }^{[20]}$; reduction of endothelial cell permeability; inhibition of TNF-alpha; identification of leukotrienes and "Endothelium-Derived Constricting Factor" (EDCF) inhibition of vasospastic effects. lloprost has found its use in many clinics today due to its pharmacological properties, especially used in critical limb ischemia, Raynaud's syndrome, and pulmonary hypertension ${ }^{[21-24]}$.

One of the most important factors affecting long-term outcome in a patient undergoing coronary artery bypass grafting is the choice of the graft to be used. The most commonly used grafts are great saphenous vein graft and IMA. As an arterial graft, the most important problem in the IMA during and after surgery is vasospasm ${ }^{[2]}$. The decision to use vasospastic IMA during surgery can put the cardiovascular surgeon in trouble. The choice of site for the anastomosis of the IMA is also an important point. Musculophrenic and superior epigastric branches should be used as short as possible (better not to use if the total length of IMA graft is long enough ${ }^{[25-27]}$, as their mechanical properties and vasospasm susceptibility are not suitable for their use. However, this part should be used in coronary artery bypass operations performed with the LAD distal. Thus, vasospasm is a problem that needs to be solved.

Factors that will affect the reliability of studies on IMA can be summarized in three main groups as follows: First, patients included in a study should be evaluated statistically concerning preoperative risk factors. Although the study groups are randomized, the lack of homogeneous distribution among the groups will affect the outcome of the study if this sensitive structure of the vascular endothelial layer is considered. We did not choose patients randomly in our study. However, we found no significant difference between the two groups concerning preoperative risk factors (Table 1). Second, it is the most commonly used segment in in-vitro studies because of the frequent use of IMA (musculophrenic and superior epigastric branches) due to its musculo-skeletal characteristics and susceptibility to vasospasm. It should be argued that it is true that only the work that is carried out on this segment reflects the whole structure of the IMA and the response given to the vasodilator agents because of the structural difference. Thus, we evaluated the answer given by IMA to the vasodilator agents in this study with the free IMA current, including the entire segment of IMA. In the histopathological examination, we did not want to examine the distal IMA. However, we overlooked this contradiction because we examined the histological level of the topical application at the level of the endothelial layer. Third, the IMA exploration should be performed by the same surgeon every time it is taken into the study. If the same surgeon is considered to be at risk of performing different explorations in different cases, this risk is at least minimized in this way. We made it possible for the same surgeon to prepare the IMAs included in this study.

Many systemic or topical pharmacological agents are used to prevent vasospasm. Systemically, diltiazem, verapamil, nitroglycerin, or milrinone infusion may be used. However, at doses, sufficient vasodilatation on IMA in systemic use, bradycardia, hypotension, low cardiac output, hemodynamic instability may occur.

Attempts have been made to increase blood flow in vasospastic IMA by methods, such as topical, intraluminal hydrostatic dilation of papaverine, or dilation with IMA probe $^{[7,8]}$. The question of whether increased blood flow through intraluminal papaverine injection is due to direct vasodilatation of papaverine or hydrostatic expansion of the IMA has not yet been answered. It has also been reported that intimal injuries and early and late IMA patency rates may be adversely affected by methods other than topical papaverine ${ }^{[7,8]}$. The success of topical papaverine in reversing spasm in the IMA has led to the search for other vasodilators as an alternative to papaverine. In an in-vitro study, nitroglycerin and nifedipine were suggested to be more effective in IMA spasm than papaverine ${ }^{[28]}$. It has been shown that papaverine is the most effective agent in reversing the IMA spasm due to potassium and norepinephrine in an in-vitro study ${ }^{[29]}$. Another study compared topical vasodilation effects of five different agents on IMA graft (papaverine, verapamil, nitroglycerine, nitroprusside), and they found no significant difference between the groups $^{[30]}$.

Prostacyclin $\left(\mathrm{PGI}_{2}\right)$ is a molecule synthesized mainly by arachidonic acid pathway by vascular endothelial cells. By inhibiting vasodilatation and platelet aggregation, iloprost plays a role in the regulation of blood flow at the microvascular level. It is chemically and metabolically more stable with similar pharmacokinetics to $\mathrm{PGI}_{2}$. At physiological $\mathrm{pH}$, 
the half-life is $20-30$ minutes $^{[31]}$. In coronary artery bypass surgery, the analgesic prostacyclin is iloprost, prevents platelet aggregation, protects lung tissue, reduces harmful effects of neutrophils, especially pulmonary vascular resistance in patients with mitral stenosis and right ventricular protective effects. There are two studies that showed the effects of iloprost in topical vasodilatation. A previous study included 3-mm IMA preparations from 24 patients in iloprost, papaverine and diltiazem solutions and looked for contraction-relaxation responses ${ }^{[32]}$. In this study, iloprost was found to be more effective than papaverine and diltiazem ${ }^{[32]}$. Another study showed the effects of iloprost as topical vasodilatation for the radial artery in 28 patients. In this study, iloprost, papaverine, diltiazem, and placebo-controlled solutions and the contraction-relaxation response for the radial artery were evaluated and they concluded that the effects of vasodilatation on the radial artery of the topical iloprost were equivalent to that of dapper tissue and that iloprost could be routinely used as a topical vasodilator ${ }^{[33]}$.

Many studies have been carried out on the amount of free flow the IMA should have. A study has shown that the initial flow of IMA is $20 \mathrm{~mL} / \mathrm{min}, 43 \mathrm{~mL} / \mathrm{min}$ before anastomosis is within normal limits ${ }^{[6]}$. The effects of the mean arterial pressure on these measurements should be considered. Our clinically shared view is the personal observation of the surgeon, who will use the IMA to evaluate the IMA current even if it seems subjective. In our study, the initial flow of IMA (Flow-1) was measured as $52 \mathrm{~mL} / \mathrm{min}$ (mean TA: $74 \mathrm{mmHg}$ ) in all patients. The pre-IMA-LAD anastomotic flow (Flow-3) was $62 \mathrm{~mL} / \mathrm{min}$ (mean TA: $56 \mathrm{mmHg}$ ) in the iloprost group and $56 \mathrm{~mL} / \mathrm{min}$ (mean TA: $56 \mathrm{mmHg}$ ) in the papaverine group.

Physiological conditions in in-vitro studies differ markedly from physiological conditions in the in-vivo environment. This difference may arise from interleukins, arachidonic acid metabolites, clotting factors, even patient saturation changes. Even if all physiological conditions are established in-vitro, the pedicular IMA does not reflect the results of invivo pedicular IMA as it is being studied for skeletonization in the graft. Thus, we evaluated the effects of iloprost on IMA according to the result of free IMA flow (with concurrent mean arterial blood pressure) after topical application, not by evaluating the contraction-relaxation response of solution preparations containing iloprost in solution.

In our histopathological evaluation, 11 of the preparations treated with topical vasodilators were desquamated at a slight degree. The desquamation rate was significantly higher in the Papaverine group (nine samples were in the papaverine group) ( $p=0.013$ ). No desquamation was observed in any of the preparations at medium or advanced $\left(2^{\text {nd }}\right.$ and $\left.3^{\text {rd }}\right)$. Papaverine may cause endothelial damage when intensively prepared due to its acidic structure. The $\mathrm{pH}$ of the isotonic solution prepared with a concentration of $2.5 \mathrm{mmol} / \mathrm{L}$ was measured as 4.4 , while the isotonic solution prepared with a concentration of $0.03 \mathrm{mmol} / \mathrm{L}$ was measured as $\mathrm{pH} 4.8^{[10]}$. In our study, $2 \mathrm{~mL}$ of papaverine (Papaverine $\mathrm{HCl} 0.05 \mathrm{~g} / 2 \mathrm{~mL}$, Biosel, Istanbul) was used by spraying on an IMA pedicle from a syringe fitted with a 26 $\mathrm{G}$ needle by diluting with $8 \mathrm{~mL}$ of isotonic sodium chloride. The $\mathrm{pH}$ was measured as 4.6 in the topical papaverine solution routinely used in this way. Since there are not enough data on the application of topical iloprost and the amount of dose to be administered, we administered topically the iloprost dose that was administered in the systemic dose. The $\mathrm{pH}$ of the topical iloprost solution was measured to 7.1. We think that the exposure of a group of the papaverine to a more acidic topical agent increases desquamation. We observed fibrotic, fibrotic and calcific plaques on 7 of 11 preparations with histopathologically examined desquamation. Fibrosis and fibrotic plaques were seen in $25 \%$ and $7.5 \%$ of the IMAs we studied. It has been reported that $2 \%$ of the atherosclerotic changes in IMA were observed ${ }^{[34]}$. Because of the desquamation, all patients with a plaque were hyperlipidemic and did not receive antilipidemic treatment. We think that starting an antilipidemic treatment if necessary by regular lipid profile scanning will result in less atherosclerotic plaque in IMAs.

Although there was a previous study about the topical iloprost effects on isolated human radial artery ${ }^{[35]}$, to our knowledge, there is no in-vivo prospective study yet to reveal the effects of topical iloprost administration on IMA blood flow compared to papaverine. In this study, we aimed to compare the topical effects of iloprost with papaverine as a primary objective and to see its effects on the cellular level as a secondary objective.

As a result, both papaverine and iloprost are successful in increasing IMA blood flow and there is no significant difference between the two groups. However, we observed that endothelium desquamation, which we considered as a secondary objective, was significantly higher in the papaverine group $(\mathrm{p}=0.013)$.

\section{Conclusion}

We concluded that iloprost could be an alternative to papaverine for topical use on IMA graft with similar vasodilatation response and lower endothelial damage rates. 
Ethics Committee Approval: Local ethics committee (Approval number: 13735).

Peer-review: Externally peer-reviewed.

Authorship Contributions: Concept: E.S.D.Y.; Design:D.G., S.N.Ö.; Data Collection or Processing: E.S.D.Y., S.H.A.; Analysis or Interpretation: S.H.A.; Literature Search: G.I.; Writing: E.S.D.Y., O.O.B.

Conflict of Interest: None declared.

Financial Disclosure: The authors declared that this study received no financial support.

\section{References}

1. Fiore AC, Naunheim KS, Dean P, Kaiser GC, Pennington G, Willman $\mathrm{VL}$, et al. Results of internal thoracic artery grafting over 15 years: single versus double grafts. Ann Thorac Surg 1990;49:202-9. [CrossRef]

2. Sarabu MR, McClung JA, Fass A, Reed GE. Early postoperative spasm in left internal mammary artery bypass grafts. Ann Thorac Surg 1987;44:199-200. [CrossRef]

3. Dregelid E, Heldal K, Andersen KS, Stangeland L, Svendsen E. Dilation of the internal mammary artery by external papaverine application to the pedicle--an improved method. Eur J Cardiothorac Surg 1993;7:158-62. [CrossRef]

4. Sasson L, Cohen AJ, Hauptman E, Schachner A. Effect of topical vasodilators on internal mammary arteries. Ann Thorac Surg 1995;59:494-6. [CrossRef]

5. Salmenperä M, Levy JH. The in vitro effects of phosphodiesterase inhibitors on the human internal mammary artery. Anesth Analg 1996;82:954-7. [CrossRef]

6. Cooper GJ, Wilkinson GA, Angelini GD. Overcoming perioperative spasm of the internal mammary artery: which is the best vasodilator? JThorac Cardiovasc Surg 1992;104:465-8. [CrossRef]

7. Johns RA, Peach MJ, Flanagan T, Kron IL. Probing of the canine mammary artery damages endothelium and impairs vasodilation resulting from prostacyclin and endothelium-derived relaxing factor. J Thorac Cardiovasc Surg 1989;97:252-8.

8. van Son JA, Tavilla G, Noyez L. Detrimental sequelae on the wall of the internal mammary artery caused by hydrostatic dilation with diluted papaverine solution. J Thorac Cardiovasc Surg 1992;104:972-6. [CrossRef]

9. He GW. Arterial grafts for coronary artery bypass grafting: biological characteristics, functional classification, and clinical choice. Ann Thorac Surg 1999;67:277-84. [CrossRef]

10. Rosenfeldt FL, He GW, Buxton BF, Angus JA. Pharmacology of coronary artery bypass grafts. Ann Thorac Surg 1999;67:87888. [CrossRef]

11. Fuster V. Alexander R, O'Rourke RA, Roberts R, editors. Hurst the heart. 10th ed. McGraw-Hill; 2001. p. 1109-26.

12. Moncada S, Gryglewski R, Bunting S, Vane JR. An enzyme isolated from arteries transforms prostaglandin endoperoxides to an unstable substance that inhibits platelet aggregation. Nature 1976;263:663-5. [CrossRef]

13. Kadowitz PJ, Chapnick BM, Feigen LP, Hyman AL, Nelson PK, Spannhake EW. Pulmonary and systemic vasodilator effects of the newly discovered prostaglandin, PGI2. J Appl Physiol Respir Environ Exerc Physiol 1978;45:408-13. [CrossRef]

14. Mulvin D, Jones K, Howard R, Grosso M, Repine J, Johnston M. The effect of prostacyclin as a constituent of a preservation solution in protecting lungs from ischemic injury because of its vasodilatory properties. Transplantation 1990;49:828-30.

15. Grant SM, Goa KL. Iloprost. A review of its pharmacodynamic and pharmacokinetic properties, and therapeuticpotential in peripheral vascular disease, myocardial ischaemia and extracorporeal circulationprocedures. Drugs 1992;43:889-924.

16. Krause W, Krais T. Pharmacokinetics and pharmacodynamics of the prostacyclin analogue iloprost in man. Eur J Clin Pharmacol 1986;30:61-8. [CrossRef]

17. Belch JJ. Effect of iloprost (ZK 36374) on white cell behaviour. In: Gryglewski RJ, Stock G, editors. Prostacyclin and its stable analogue iloprost. Berlin-Heidelberg: Springer-Verlang; 1987. p. 97-102. [CrossRef]

18. Lowe GDO, Rumley A. The biochemistry of critical limb ischaemia. Critical Ischaemia 1991;1:11-23.

19. Scott JP, Higenbottam T, Wallwork J. The acute effect of the synthetic prostacyclin analogue iloprost in primary pulmonary hypertension. Br J Clin Pract 1990;44:231-4.

20. Stürzebecher CS, Loster W. Effects of iloprost on platelet activation in vitro. In: Gryglewski RJ, Stock G, editors. Prostacyclin and its stable analogue iloprost. Berlin- Heidelberg: Springer-Verlang; 1987. p. 39-45. [CrossRef]

21. Dormandy J. Use of the prostacyclin analogue iloprost in the treatment of patients with critical limb ischaemia. Therapie 1991;46:319-22.

22. Altstaedt HO, Berzewski B, Breddin HK, Brockhaus W, Bruhn $H D$, Cachovan $M$, et al. Treatment of patients with peripheral arterial occlusive disease Fontaine stage IV with intravenous iloprost and PGE1: a randomized open controlled study. Prostaglandins Leukot Essent Fatty Acids 1993;49:573-8.

23. Schuller-Petrovic S, Siedler S, Kern T, Meinhart J, Schmidt K, Brunner F. Imbalance between the endothelial cell-derived contracting factors prostacyclin and angiotensin II and nitric oxide/cyclic GMP in human primary varicosis. Br J Pharmacol 1997;122:772-8. [CrossRef]

24. Wigley FM, Wise RA, Seibold JR, McCloskey DA, Kujala G, Medsger TA Jr, et al. Intravenous iloprost infusion in patients with Raynaud phenomenon secondary to systemic sclerosis. A multicenter, placebo-controlled, double-blind study. Ann Intern Med 1994;120:199-206. [CrossRef]

25. Brown MW, Jones EL. First operation for myocardial revascularization. In: Edmunds $\mathrm{HL}$, editor. Cardiac Surgery in the Adult. Philadelphia: Mc Graw Hill; 1997. p. 535-72.

26. Pompilio G, Rossoni G, Alamanni F, Tartara P, Barajon I, Rumio $C$, et al. Comparison of endothelium-dependent vasoactivity of internal mammary arteries from hypertensive, hypercholesterolemic, and diabetic patients. Ann Thorac Surg 2001;72:1290-7. [CrossRef]

27. Higami T, Kozawa S, Asada T, Shida T, Ogawa K. Skeletonization and harvest of the internal thoracic artery with an ultra- 
sonic scalpel. Ann Thorac Surg 2000;70:307-8. [CrossRef]

28. Pohl U, Holtz J, Busse R, Bassenge E. Crucial role of endothelium in the vasodilator response to increased flow in vivo. Hypertension 1986;8:37-44. [CrossRef]

29. Jett GK, Guyton RA, Hatcher CR Jr, Abel PW. Inhibition of human internal mammary artery contractions. An in vitro study of vasodilators. J Thorac Cardiovasc Surg 1992;104:977-82.

30. Us MH, Pekediz A, Süngün M, İnan K, Çağlı K, Yıldırım Ş, et al. Are Vasodilator Drugs Necessary During Internal Thoracic Artery Preparation. Türk Göðüs Kalp Damar Cer Derg 2003;11:5-8.

31. Armstrong DG, Nguyen HC, Lavery LA, van Schie $\mathrm{CH}$, Boulton AJ, Harkless LB. Off-loading the diabetic foot wound: a randomized clinical trial. Diabetes Care 2001;24:1019-22.

32. Serbest MO, Soner BC, Sariosmanoglu ON, Kalkan S, Guven
H, Ugurlu B, et al. Vasorelaxant effect of iloprost on isolated human internal mammary artery. Fundam Clin Pharmacol 2007;21:75-9. [CrossRef]

33. Ozdemir C, Ikizler M, Besogul Y, Karakaya A, Sirmagul B. An alternative agent for radial arterial graft spasm: application of topical iloprost. Scand Cardiovasc J 2007;41:201-6. [CrossRef]

34. Krijne R, Mario $\mathrm{CH}$, Heinrich KW, Sons H, Krian A. Semiselective angiography of the internal mammary arteries as a preparation for coronary bypass surgery. The American journal of cardiology 1990;66:377-8. [CrossRef]

35. Engin E, Alp Yildirim Fi, Kaleli Durman D, Ömeroğlu SN, Göksedef D, Teskin Ö, et al. Relaxant effect of the prostacyclin analogue iloprost on isolated human radial artery: An approach for the reversal of graft spasm. Prostaglandins Other Lipid Mediat 2017;133:35-41. [CrossRef] 